\title{
The Natural Resources Governance as a Moderation for the Effect of Natural Environment on Community Based Empowerment (Case study in Ringgung Beach Bandar Lampung)
}

\author{
Yuni Astuti \\ Catur Widayati \\ Universitas Mercu Buana
}

\begin{abstract}
Tourism in Indonesia is growing rapidly as well as tourism in the beach areas, this is encouraging the empowerment of coastal community communities. The environment has to be managed properly and correctly and sustainably. If it is not managed properly there is a serious problem can be damage to the coastal area so that the impact on the low empowerment of coastal communities. This study aims to analyze the importance of managing natural resource management in moderating the natural environment towards empowering tourism-based communities in Bandar Lampung's Sari Ruding Beach. The population in were 52 in the Sari Ruding Beach in Bandar Lampung. The sampling technique uses the saturation sample technique (population research). Data collection methods in this study is using a survey method with research instruments using a closed questionnaire. The results of data analysis, it was found that the natural environment has a positive effect on empowerment of tourism-based communities, natural resource governance does not affect the empowerment of tourist communities, and natural resource governance does not act as a moderation for the natural environment. Effect of the Natural Environment on Community Empowerment so that it can continue to be improved, it is necessary to maintain the environment of marine life by limiting snorkeling, swimming and playing spots that can damage the marine ecosystem.
\end{abstract}

Keywords: Governance, Natural Resources, Community Empowerment, Beaches

DOI: $10.7176 / \mathrm{JESD} / 10-18-13$

Publication date:September $30^{\text {th }} 2019$

\section{INTRODUCTION}

The Bandar Lampung city government is intensively developing the tourism potential of the beach, including Sari Ruding Beach which is located on Jalen Ratay 14 in the village of Sidodadi, Teluk Pandan, Pesawaran Regency. Sari Ruding Beach opened in 2014, undergoing renovation and development but it has not been maximized. The facilities provided need to be developed such as parking lots, bathrooms, food and beverage vendors and souvenir shops, toys on the beach, boats for fishing at sea, snorkeling equipment rentals. The beach is open from 06.00 to 17.00 WIB, the access road is well paved even though some places have broken holes and are not wide enough. The phenomenon that occurs when it rains in tourist areas inundated by high water around food stalls, drinks and souvenirs, as well as tourist attractions on Sari Rober Beach such as the Floating Mosque, Embossed Sand, Snorkeling Spots, Swimming and Children's Play Spots, Pondok and Gazebo less desirable when it rains.

The governance in this study is an attempt made to create a usability on certain objects so that they have more value and revive existing functions or potentials (Wongso, 2017). While Natural Resources is anything that comes from nature and consists of various components such as land, mountains, valleys, rivers, waterfalls, rain, etc. which can be used to meet the needs to improve the welfare of living things. The Natural Resources referred to in this study are the Sari Ruding Beach in Bandar Lampung (Hendrymahendra, 2017). Tourism-based community empowerment is an effort to improve the welfare and quality of life of the community, through the utilization of the potential, capital or environmental assets that are managed into the tourism sector by the community itself.

According to the results of research by Cole (2011) and Sutawa (2012) environmental problems and the natural environment remain a central theme in tourism. Tourism has the potential to empower people and realize sustainable tourism. In sustainable tourism, natural resource management is needed that can moderate (improve) the natural environment from less efficient to more efficient so that it can increase the empowerment of surrounding communities. According to Okazaki (2008), indigenous peoples previously initiated communitybased ecotourism projects. To be sustainable, natural resource management is needed, so that community-based tourism can go down to the next generation (Knigt and Cottrell (2016). Based on the results of research Resnawaty (2016) coastal communities have the weakness of the lack of development of skills change from fishing communities to tourism communities, as well as the results of Akbar's research (2018) the lack of Human Resources in terms of education becomes a problem for the development of local communities. This problem can be overcome if natural resources are good and attractive with clean white sandy beaches, waves that are not so big, and bordered by verdant hills that can be managed properly and sustainably, then this area has the potential to be visited by many local and international tourists. This can increase the income of the local community through 
tourism-based community empowerment by improving the management of its natural resources. The novelty of this research is to increase community empowerment naturally by increasing the potential of its natural environment. The purpose of this study is to find out whether Natural Resource Governance can increase the potential of the Natural Environment so that it can increase the empowerment of tourism-based communities in Bandar Lampung's Sari Ruding Beach. Thus the development is expected to create productive resources or livelihoods for the surrounding community, more than that the community can meet their daily needs independently (Michell, 2000).

Based on the above research phenomena it is interesting to examine the importance of natural resource governance as a moderation of the influence of the natural environment on the empowerment of a tourism-based community in Bandar Lampung's Sari Ruding Beach.

\section{CONCEPTUAL FRAMEWORK AND HYPOTHESES DEVELOPMENT}

Relationship of the Natural Environment and Community Empowerment Natural Resources is anything that comes from nature and consists of various components such as land, mountains, valleys, rivers, waterfalls, forests, seas and others that can be used to meet the needs of living things (Hendrymahendra, 2017). Community-based tourism as an empowerment approach that involves the community as an important actor in sustainable development. Community-based tourism is an opportunity to mobilize all the potential and dynamics of the community, in order to offset the role of large-scale tourism businesses. Community-based tourism does not mean mere small and local efforts, but needs to be put in the context of global community cooperation (Sastrayuda, 2010). Based on the above, the hypotheses tested are:

H1: The Natural Environment has a positive effect on Community Empowerment.

b. Relationship of Natural Resource Governance and Community Empowerment

In etymology governance means a process of reactivating or reviving. The governance referred to in this study is an attempt made to create a usability in a particular object so that it has more value and revives existing functions or potentials (Wongso, 2017). Community-based tourism as an empowerment approach that involves the community as an important actor in sustainable development. Community-based tourism is an opportunity to move all the potential and dynamics of the community, in order to offset the role of large-scale tourism business actors (Sastrayuda, 2010). Based on the explanation above, the hypotheses that can be built are:

H2: Natural Resource Governance has a positive effect on Community Empowerment.

c. The Relationship of Natural Resource Governance as a Variable of Moderation and Community Empowerment Governance is an effort to re-manage an area that was once vital or alive, but has declined, with the aim of providing a more productive new life that is able to make a positive contribution to the social, cultural and economic life of the community (Wongso, 2017).

In the concept of community-based tourism contained therein is the concept, community empowerment efforts, which are always associated with the characteristics of the target as a community that has the characteristics, background, and community empowerment, the most important thing is to begin with how to create an atmosphere, or climate that allows potential community to develop (Sastrayuda, 2010)

H3: Natural Resource Governance as a moderating variable has a positive effect on Community Empowerment.

\section{RESEARCH METHODOLOGY}

The research method used was a survey method. Use questionnaire tools to respondents to collect data in measuring natural environment variables and Natural Resource governance in increasing community empowerment. The study was conducted from February to August 2019. Measurement of Community Empowerment variables using Resnawaty (2016), natural environment using Hendrymahendra (2017) and SDA Governance (Wongso, 2016). The population in this study was 54 traders in Sari Ruding Beach. Because the number of traders is only 54 people, the number of samples are all taken, this is called the saturated sample. Data Analysis Method uses Partial Least Square (PLS).

\section{ANALYSIS RESULTS AND DISCUSSION}

Characteristics of Respondents. Characteristics of respondents can be seen by sex, the number of female respondents is higher than male, 38 female and 16 male. Based on the age of the respondent spread between 19 65 years, the respondent's residence also spread around the Sari beach area and the length of stay also spread between 1 - 10 years.

Analysis test results with Partial Least Square, Evaluation of Measurement Model (Outer Model).

a) Validity Test

Validity testing is done in two ways, namely Convergent and Discriminant Validity. According to Chin in Ghozali and Latan (2015), an indicator has convergent validity if the loading factor value is greater than 0.50 . The test results are shown in Figure 1. It appears that there are several indicators having a loading factor value of less than 0.5 , namely LA3 (0.080), LA5 (0.458), TK2 (0.486) and PM6 (0.367). Then the indicator is invalid then eliminate 


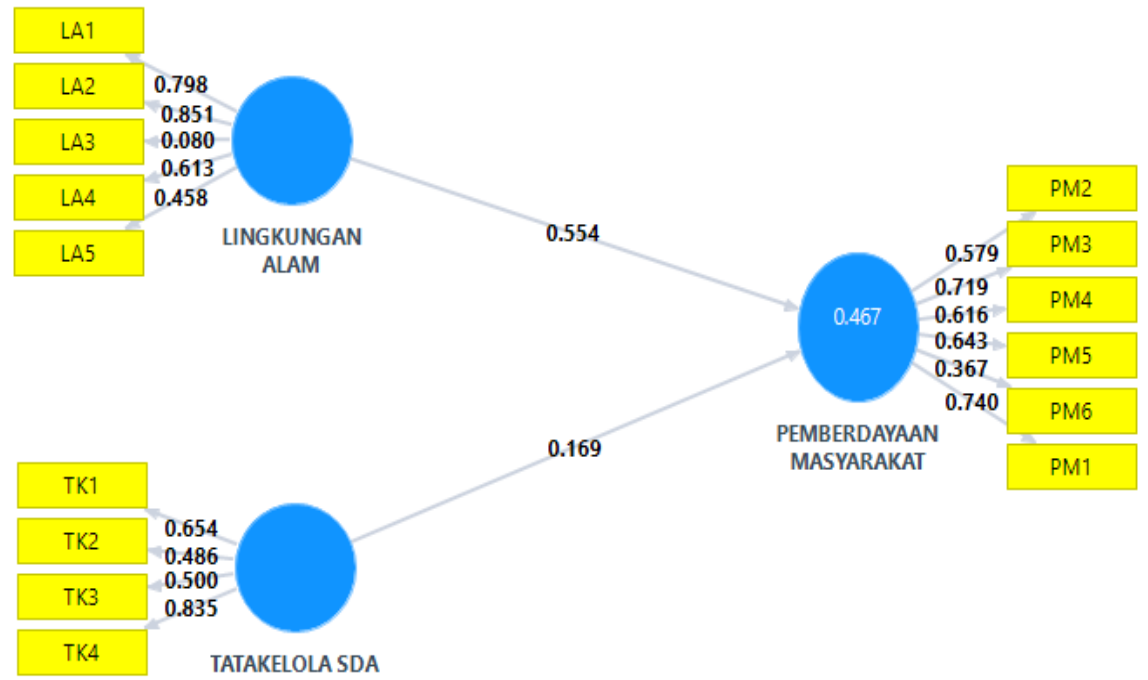

Figure 1 : Convergent Validity

Source : primary data, 2019

After invalid indicators are eliminated, then the calculation is repeated. The following results are the output of the removal of the indicator and are calculated again with the following results

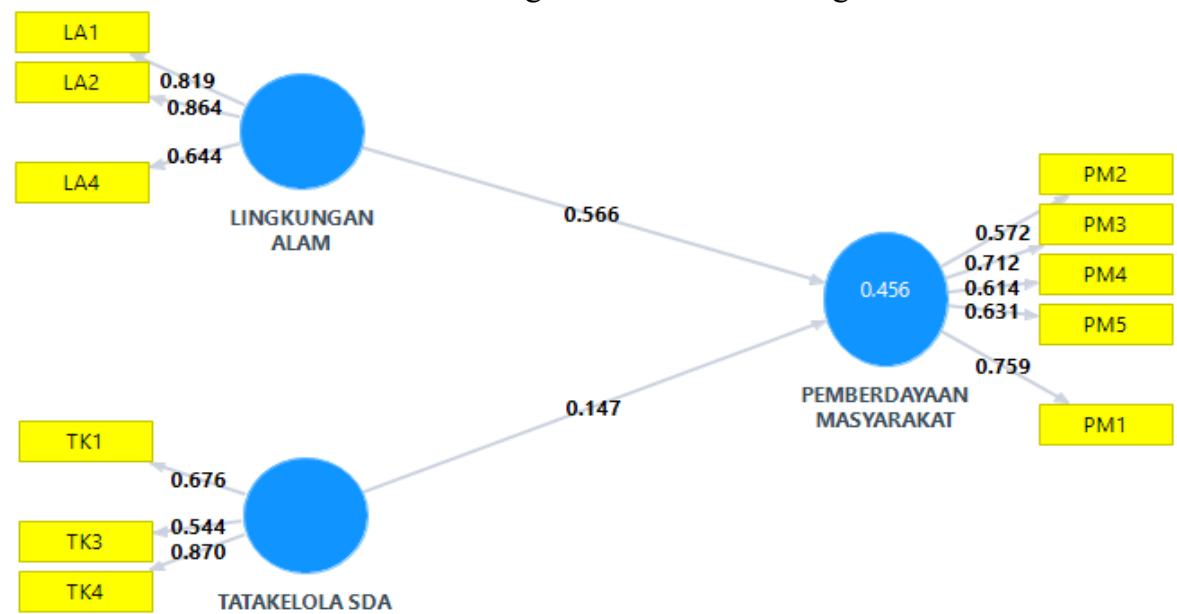

Figure 2 : Convergent Validity

In Figure 2 shows the indicators of the three variables namely the Natural Environment, Natural Resource Governance and Community Empowerment are all valid. This shows that the indicators are the correct tools as a questionnaire and the data generated can be further tested.

Discriminant Validity

Discriminant validity is analyzed by comparing the value of the square root of AVE and the correlation value between constructs, shown in Table 1, that all square root values of each construct (written in bold), have a higher value than the correlation between other constructs. Thus it can be concluded that the measurement of variables has good discriminant validity.

Table 1. Hasil Discriminant Validity

\begin{tabular}{lccc}
\hline & Environment & Community empowerment & Natural resources Governance \\
\hline Environment & $\mathbf{0 , 7 8 2}$ & & \\
Community empowerment & 0,667 & 0,661 & $\mathbf{0 , 7 0 9}$ \\
Natural resources Governance & 0,686 & 0,536 & $\mathbf{0 , 7 0 9}$ \\
\hline
\end{tabular}

Sources: Smart PLS seri 3, 2018

b) Reliability Test

Composite Reliability and Cornbachs Alpha

Composite reliability testing and Cornbachs alpha aims to test the reliability of natural instruments of a research model or measure internal consistency and the value must be above 0.7 . If all latent variable values have composite reliability and Cronbach Alpha values $>0.7$. This means that the construct has good reliability or the questionnaire is used reliably as a tool in research 
Table 2. Composite Reliability dan Cornbachs Alpha

\begin{tabular}{lcccc}
\hline \multicolumn{1}{c}{ Variabel } & Composite Reliability & Ref & Cronbachs Alpha & Ref \\
\hline Environment & 0,746 & Reliable & 0,689 & Not Reliabel \\
Community empowerment & 0,794 & Reliable & 0,686 & Not Reliabel \\
Natural resources Governance & 0,823 & Reliable & 0,486 & Not Reliabel \\
\hline
\end{tabular}
source: Smart PLS, 2018

Composite Reliability and Cronbach's Alpha Testing aims to test consumer reliability in a research model or measure internal consistency and the value must be above 0.7 . In this study all latent variables such as the Natural Environment, Community Empowerment and SDA Governance have Composite Reliability values $>0.70$, meaning that the construct has a high degree of reliability or the questionnaire used as a tool in this study has been reliable or consistent. When viewed from the Cronbachs Alpha value $<0.70$ it means that the construct has a moderate degree of reliability. According to Guilford in Suherman (2003) uses the following degrees of reliability:

Table 3. Guilford reliability test

\begin{tabular}{cccc}
\hline No. & Score & Reference \\
\hline 1 & $0,90-1,00$ & very high & \\
2 & $0,70-0,90$ & high & \\
3 & $0,40-0,70$ & moderate & \\
4 & $0,20-0,40$ & low & \\
5 & $0,00-0,20$ & very low & \\
\hline
\end{tabular}

Source : Guilford in Suherman, 2003

2) Evaluation of Structural Models / Hypothesis Test (Inner Model)

a) Goodness of Fit Model Test

Testing the inner model is the development of concept-based models and theories in order to analyze the relationship between exogenous and endogenous variables have been described in the conceptual framework. The stages of testing the structural model (inner model) are carried out with the following steps:

$\mathrm{R}$ square Value

See the value of $\mathrm{R}$ square which is a test of goodness of fit model

Table 4. $\mathrm{R}^{2}$ Variable Endogen

\begin{tabular}{lll}
\hline Variable Endogen & R Square & Rsquare Adjusted \\
\hline Community empowerment ( Y ) & 0,455 & 0,435 \\
\hline
\end{tabular}

Sources : Output PLS (2018)

The structural model indicates that the model on the Community Empowerment variable can be said to be weakly positive because it has a value below 0.5 or below $50 \%$. The model of the influence of the independent latent variable Natural Environment and Natural Resource Management) on Community Empowerment gives an $\mathrm{R}$ square value of 0.435 or $43.5 \%$, which can be explained that Community Empowerment is influenced by the Natural Environment and Natural Resources variable of $43.5 \%$, while $56.50 \%$ is influenced by variables other than the Natural Environment and SDA Governance.

b) Hypothesis Testing

To find out significant by comparing significant values that occur with a confidence level of 0.05 . If the significant value that occurs (indicated by $\mathrm{P}$ value) is smaller than the 0.05 confidence level, then the hypothesis is accepted. From the results of the path coefficient as shown in Table 5 can be seen the results of testing this research hypothesis. The estimated value for the path relationship in the structural model must be significant which can be obtained by the bootstrapping procedure. See the significance of the hypothesis by looking at the value of the parameter coefficient and the value of the significance of T-statistics on the algorithm bootstrapping report. To find out significant or insignificant seen from the T-table at alpha $5 \%(0.05)=1.96$, then the T-table is compared with the T-count (T-statistic).

Table 5. Hipothesis test

\begin{tabular}{|c|c|c|c|c|c|c|}
\hline Variable & & $\begin{array}{l}\text { Original } \\
\text { sample }\end{array}$ & $\begin{array}{l}\text { Standard } \\
\text { deviation }\end{array}$ & $\begin{array}{l}\mathrm{T} \\
\text { statistic }\end{array}$ & $\begin{array}{l}\mathrm{P}- \\
\text { value }\end{array}$ & Ref \\
\hline $\begin{array}{l}\text { Nature to } \\
\text { empowerment }\end{array}$ & Community & 0,566 & 0,112 & 5,035 & 0,00 & Positive Sign \\
\hline $\begin{array}{l}\text { Governance } \\
\text { empowerment }\end{array}$ & Community & 0,147 & 0,116 & 1,270 & 0,205 & $\begin{array}{l}\text { Positive } \\
\text { Sign }\end{array}$ \\
\hline
\end{tabular}

Sources : Output Smart PLS seri 3 (2019)

Table 5 explains the results of hypothesis testing, between the natural environment and the management of natural resources for community empowerment.

1) The natural environment has a significant positive effect on community empowerment. Table: 1.96 at the 0.05 level. Besides that also by looking at the P-value of 0.00 smaller than 0.05 . The better the natural environment, the 
more empowered the community will be. The results of this study are supported by Nurdin's research (2016) in which Samalona Island is very feasible to be developed as a community-based tourist destination.

2) SDA governance does not affect Community Empowerment. This is indicated by the T-statistic value of 1.270 smaller than Ttable: 1.96 at the 0.05 level. In addition, by looking at the P-value of 0.205 , greater than 0.05 . The results of this study contradict hypothesis 2, this is because the value of the SDA governance factor loading associated with creativity is of low value, for example a canoe group competition is held. The results of this study support the results of Akbar's research (2018), namely the low level of human resources in terms of education is a problem for the development of local communities.

3) Moderating Effect output Figure 3 shows the results that natural resource management cannot be as a moderating effect on the natural environment, meaning that there is no moderating relationship or the construct of natural resource management is not a moderation construct because 0.058 is greater than 0.05

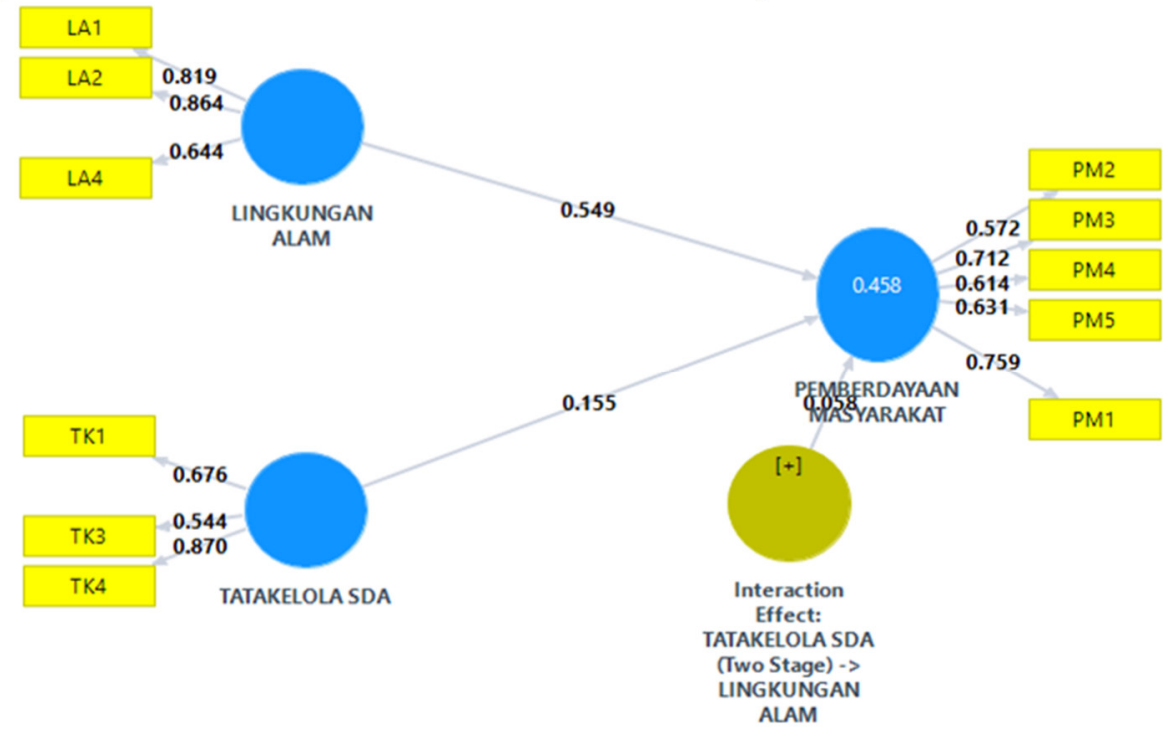

Figure 3. Results of Moderating Effect Output

Source: Smart PLS series 3 output (2019)

\section{c. DISCUSSION}

1) Effect of the Natural Environment on Community Empowerment

The results of hypothesis testing prove that hypothesis 1 is accepted, that the natural environment has a positive effect on community empowerment. When analyzed using a loading factor that increased tourism-based community empowerment is very dominant, this requires natural management of the beach area to expand tourist activity. Based on hypothesis testing, it shows that the Natural Environment influences Community Empowerment. The better the natural environment, the more empowered the community will be. The results of this hypothesis are strengthened by the results of Nurdin's research (2016). This result is also supported by the results of research by Astini and Sulistiyowati (2015) in which community empowerment will increase with an increase in the quality of service to increase visitors.

In addition, the results of this study are supported by the results of research by Cole (2011) and Sutawa (2012) environmental problems and the natural environment remain a central theme in tourism. Tourism has the potential to empower people and realize sustainable tourism. According to Okazaki (2008), indigenous peoples previously initiated community-based ecotourism projects. To be sustainable, natural resource management is needed, so that community-based tourism can go down to the next generation (Knigt and Cottrell (2016).

2) The Effect of Natural Resource Governance on Community Empowerment

Hypothesis 2 cannot be proven in this study, that the management of natural resources does not affect the empowerment of tourism-based communities. The research findings support Nurdin's (2016) research which states that the strategy for developing human resources is still weak. Besides that it can also be seen from the coefficient of determination in this study that the value of $43.5 \%$ indicates that community empowerment is influenced by the natural environment in Sari Ruding Beach and its Management by $43.5 \%$ while $56.5 \%$ is influenced by variables other than the natural environment and its management. Meanwhile according to Zielinski et al (2019) states that there are weaknesses in policies designed for environmentally friendly tourism in encouraging community-based tourism.

3) Effect of Governance Natural resources as a moderating variable of the natural environment on community empowerment

Hypothesis 3 cannot be proven in this study. Natural Resource Governance as a moderating variable in the natural 
environment does not affect Community Empowerment. Moderating effect Natural resource management cannot improve the natural environment for community empowerment. This is due to the fact that coastal communities are not ready to accept the management of natural resources, this can be seen from the relatively low loading factor value (0.572), namely the development of small-scale tourist objects and attractions managed by local communities. According to Wongso (2017) governance is an effort made to create a usability in certain objects to have more value and to revive existing functions or potentials. Judging from the value of the loading factor of low SDA management, for example in Sari Rober Beach there is a creativity competition made of white sand, a fishing competition at sea, a group canoe competition, meaning that the local community is not ready for holding governance at Sari Ruding Beach. The results of this study support the research of Resnawaty (2016) in which coastal communities have the weakness of a lack of skills change from fishing communities to tourism communities. Also Nurdin's research results (2016) prove that the Human Resources development strategy is still weak.

\section{CONCLUSION}

Based on the previous description, it can be concluded, that the Natural Environment has a positive effect on Community Empowerment. The better the natural environment, the more empowered the community will be. Natural resource governance does not affect Community Empowerment. The governance of natural resources as a moderating effect does not increase the empowerment of local tourism communities.

Effect of the Natural Environment on Community Empowerment so that it can continue to be improved, it is necessary to maintain the environment of marine life by limiting snorkeling, swimming and playing spots that can damage the marine ecosystem. The Effect of Natural Resource Governance on Community Empowerment can be carried out research in other places with the same variables and indicators, the results of which make it possible elsewhere there is an influence between the management of natural resources on the empowerment of local tourism communities. The influence of moderating natural resource governance (SDA) effects can be carried out research in other places with the same variables and indicators, the results of which allow the effect of governance of local natural resources to the empowerment of the local tourism community.

\section{REFERENCES}

Akbar, MA (2018). Pengembangan Desa Wisata Budaya Berbasis Masyarakat Di Dusun Sade Desa Rembitan Kabupaten Lombok Tengah. Fisip Uinersitas Muhammadiyah Malang.

Arifi, Z (2017). Pemberdayaan Masyarakat Berbasis Pariwisata (Studi kasus AMAN (Asosiasi Asongan Mandalika ). Di Desa Kuta Kecamatan Pujut Kabupaten Lombok Tengah Nusa Tenggara Barat. Tesis, Pasca Sarjana UIN Sunan Kalijaga Yogyakarta.

Astini, R dan Sulistiyowati, I (2015). Pengaruh Destination Image, Travel Mutivation dan Kualitas Pelayanan Terhadap Kepuasan Pengunjung (Studi Kasus Pada Wisatawan Nusantara Muslim di Pantai Carita Pandeglang Banten, Jurnal Ilmiah Manajemen dan Bisnis, 1(3): 1-10

Bungin, Burhan (2001). Metodologi Penelitian Sosial (Format-Format Kuantitatif dan Kualitatif ), Airlangga University Press. Surabaya.

Cole, S (2011). Information and Empowerment: The Keys to Achieving Sustainable Tourism. Journal of Sustainable Tourism, 14 (6): $629-644$

Dodds, R; Ali, A and Galaski, K (2018). Mobilizing knowledge: determining key elements for success and pitfalls in developing community-based tourism. Current Issues I Torism, 21(13): 1547 - 1568

Hendrimahendra (2017). Azas-azas Pengetahuan Lingkungan dan SDA. http://hendrymahendra wordpress.com/2015/10/08 asas-asas-pengetahuan lingkungan-sumber-daya-alam/diakses tgl 24 Februari 2017.

Knight, D.W and Cottrell, S, P. (2016). Evaluating tourism-linked empowerment in Cuzco, Peru. Annals of Tourism Research, 56: $32-47$

Nur, F; Sebastian,K; Diah, S; Muafi (2019). The Development of Community Based Tourism: from Attractiveness to Loyalty. Bucharest, 20: 393 - 399

Nurdin (2016). Strategi Pengembangan Pariwisata Berbasis Masyarakat Di Pulau Samalona, Makasar. Jurnal Jumpa, 3(1): 175 - 189

Nurhayati, dan Fandeli (2012). Penerapan Prinsip Community Based Tourism (CBT) Dalam Pengembangan Agrowisata di Kota Batu Jawa Timur. Jurnal Jejaring Administrasi Publik, 4(1): 36 -46

Okazaki, E (2008). A Community-Based Tourism Model: Its Conception and Use. Journal of Sustainable Tourism, $16(5): 511-529$

Pambudi, A (2018). Revitalisasi Sumber Daya Alam Sebagai Model Pemberdayaan Masyarakat Berbasis Wisata (Studi di Taman Tebing Breksi Desa Sambirejo, Prambanan Sleman). Skripsi, Program Studi Pengembangan Masyarakat Islam. Fakultas Dakwah dan Komunitas Universitas Islam Negeri Sunan Kalijaga Yogyakarta.

Pramanik, PD; Ingkadijaya, R dan Achmadi M (2019). The Role of Social Capital in Community Based Tourism. 
Journal of Indonesian Tourism and Development Studies. 7(2): 62 -73

Resnawaty, R (2016). Strategi Community Practice Dalam Pengembangan Pariwisata Berbasis Masyarakat. Social Work Jurnal, 6(1): 1 - 153

Sastrayuda, G, S (2010). Hand out Mata Kuliah Concept Resort and Leisure Strategi Pengembangan dan Pengelolaan Resort and Leisure.

Schiffman, Leon dan Leslie Lazar Kanuk, (2007). Perilaku Konsumen, alih bahasa Zoelkifli Kasip, PT Indeks. Jakarta.

Sugiyono. (2010). Metode Penelitian Kuantitatif Kualitatif dan $R \&$ D. Alfabeta. Bandung.

Suharyadi dan Purwanto, (2004). Statistika Untuk Ekonomi dan Keuangan Modern. Jilid 2. Salemba Empat. Jakarta.

Sujali (2008). Pengelolaan Usaha Jasa Pariwisata Berbasis Pengembangan Masyarakat Pada Kawasan Ubud Bali, Jurnal Majalah Geografi Indonesia (MGI), 22 (2): 145 -164

Sutawa, G.K. (2012). Issues on Bali Tourism Development and Community Empowerment to Support Sustainable Tourism Development. Procedia Economics and Finance, 4: 413 - 422

Wang,S (2019). Residents' perceptions of community-based disaster tourism: the case of Yingxiu, China. Asia Pacific Journal of Tourism Research , 4 (7): 669 - 678

Wongso, J (2017). Strategi Revitalisasi Kawasan Pusat Kota Bukittinggi. Jurnal online / Jurusan Teknik Arsitektur Fakultas Teknik Sipil dan Perencanaan Universitas Bung Hatta Padang.

$\mathrm{Xu}, \mathrm{H}$; Jiang, F; Wall, G dan Wang, Y (2019). The evolving path of community participation in tourism in China. Journal of Sustainable Tourism, 27 (8): 1239 - 1258 